\title{
An Assessment of the Muslim Structure and Methodology of Teaching the Qur'ān in Slate Schools (Makarantun Allo) in Nasarawa State, Nigeria
}

\author{
Abdullahi Adamu Sulaiman, \\ Department of Religious Studies (Islamic Studies Unit), Nasarawa State University, Keffi, Nasarawa State, \\ Nigeria.
}

\begin{abstract}
Islamic education is as old as the religion of Islam itself. The religion of Islam encourages learning right from its advent. The fact that the Qur'ān and the Sunnah of the Prophet (S.A.W.) contained instructions on the quest of knowledge is a clear testimony to this fact. Therefore in every generation, from the time of the Prophet (S.A.W.), there exist Muslims scholars who are very much keen in the pursuit of learning and zealous in imparting knowledge to others. It is discovered that Makarantun allo in Nasarawa State is currently losing its relevance virtually due to the priority given to the modern secular school system. This article unveils that the structure of Makarantun allo and its organization is such that morality, social cohesion, solidarity, cooperation, discipline and communal responsibility is infused in the mind of the pupils. Therefore the paper recommend that the system should be strongly upheld and supported so that the essence of Islam could be greatly enhanced.
\end{abstract}

keywords- slate, school, Muslim, child, learning, alphabet, teacher, methodology, Qur'ān, teaching. keyterms- makarantun allo, makaranta, allo, tawwada, alkalami, dorina, zayyana, zaure, almajirai, masallatai, malamai, rumfa, ijazat, Sunnah ${ }^{l}$

\subsection{Background to the Study}

\section{Introduction}

Makaranta (school) Makarantu (schools) and Allo (slate) are two Hausa language words put together to refer to a traditional Islamic institution of learning particularly, for the Muslim children. It is the earliest centers of learning where Muslim children gathered round the teachers who taught them how recite and write the Qur'ān (Malam Muhammad Awwal) ${ }^{2}$. In Makarantun allo, the wooden slate is considered as the major apparatus in the learning process right from the earliest period of Islam particularly in Africa (Malam Muhammadu Adamu) ${ }^{3}$. Ibn Alhaj Abdari mentioned in his book Madkhal the use of wooden slate as an instrument of learning by the Muslims Children in many Islamic educational centers. This is a clear indication that the wooden slate had been in use for a long time among different Muslim communities particularly in Africa (143:1995). Islam and its tradition of learning reached different corners of the Muslims world through the effort of literate individuals and group of scholars. Through the same means, former Hausaland and Borno which comprises the present day Northern Nigeria including Nasarawa State came into contact with Islam and its tradition of learning. The teachings of Qur'ān became a clear guide leading to the steady progress and subsequent development of Islamic education. The companions of the Prophet (SAW) had played major role toward achieving this objective. Thus, under Umayyad, Abbasid and other subsequent regimes, Islamic education developed, reaching different corners of north and west Africa including Hausa land (Gada, 8:2010) and eventually Nasarawa State.

The major factors which influenced the acceptance of Islam and its tradition of education are both internal and external. Alhaji Malam Muhammad Awwal (the deputy chief Imam, Keffi central mosque) in an oral interview noted that "some individuals and group of scholars identified to have visited Nasarawa State for the purpose of teaching and preaching included some from Kano, Katsina, Sokoto, Zazzau, Borno and Nupe land" (Malam Muhammad Awwal). Their arrival and efforts in the dissemination of Islamic learning were identified to be the major factors for the emergence and development of Islamic education in Nasarawa State.

\footnotetext{
${ }^{1}$. Keywords and terminologies used in Makarantun allo in Nasarawa State.

${ }^{2}$. Malam Muhammadu Awwal is the Deputy Chief Imam of Keffi Central Mosque in an interview on the $20^{\text {th }}$

October, 2012 at Ang. Makwalla Keffi, Nasarawa State, Nigeria.

${ }^{3}$ Malam Muhammadu Adamu is a teacher of Makarantar allo at Anguwan Rimi Keffi, Nasarawa State, Nigeria, in an interview on the $21^{\text {st }}$ October, 2012

${ }^{4}$ Malam Muhammadu Awwal. Opcit
} 
On the other hand, the ability of the indigenous scholars to receive proper training and orientation from the hands of their visiting scholars led to the dissemination and reformation of the socio-cultural and religion habits of the people of Nasarawa State. Therefore, Islamic education as a form of intellectual pursuits that gave birth to spiritual, social, economic, scientific and technological development of mankind, is basically religious in its aims and objectives. This form of education existed within the areas covered by this research since the period when Islam, as a religion, was introduced to its inhabitants. The traditional Islamic system of education was the general framework within which the Islamic education operated and developed. The system evolved and developed as a result of the new faith brought by Prophet Muhammad (S.A.W) which is enshrined in the Qur'ān. In Northern Nigeria, the system made its inroad together with Islam. Elementary, and later, higher centers of learning were gradually established to cater for the need of the new converts. According to Hiskett:

As towns and cities of the Sahara, the Sahel and the Savannah were won over to Islam, so there developed within them elementary schools and institutions of higher learning that followed a ascertained pattern. The basis of the system was the Qur'anic school, (Makarantun allo). Above this, were Makarantun 'Ilimi (55: 1985).

The historical evolution of Makarantun allo which later gave rise to the emergence of Makarantun 'Ilimi among the different Muslim communities became the main force that led to the development of Islamic education in Nasarawa State. The former is the school for the beginners, while the latter is a school for higher studies embracing all aspect of Islamic subjects (Fafunwa 61-62: 1970). The schools slightly differ in their curriculum contents. In the higher school, the students are expected to know the meaning of what they memorized from the text and translates that meaning into action, while it is not so in the lower school. However, in both higher and lower schools, rote-learning is a key teaching methodology of the teachers.

Since the goals of Makaratun allo are to infuse the complete knowledge of the Qur'ān and Islamic rites as a way of absorbing moral values and spiritual sanctity for the individual here on earth and in the hereafter, specific objectives of the Makaratun allo include the following:

(i) ensure that children read and recite the Qur'ān

(ii) children become fully inducted into Islamic moral values in all behaviours, and

(iii) children become as knowledgeable in Arabic language and basic Islamic Sciences as a foundation for further studies.

At the formal level of operations, the Qur'anic school programmes are classified into 3 distinct stages or levels. The first being the elementary or infant stage caters for children between the ages of 3 and 7 years. Then there is the intermediate state, which caters for children mainly between the ages of 8 and 12 years. While the 3rd stage is the adult or advanced studies class targeting adult learners of varying ages generally from 13 years and above. One common thing observable across the Qur'anic schools is that there is no clear-cut demarcation of learners by age factor or class as instruction in such schools is strictly individualized. Furthermore, enrolment into the Qur'anic schools is not limited by age or timeframe. Learners can enroll at anytime and at whatever age since every individual learner moves at his or her own pace.

\subsection{Classrooms of Makarantun Allo in Nasarawa State}

Mosques (Masallatai) were the earliest centers for Islamic education. Abdullahi Ibn Fodiyo (53: 1990) believes that teaching in the Mosque will make knowledge accessible to all students of learning. Consequently, in Nasarawa State, Makarantun allo started to spring up in the mosques, closer to the mosques and in private houses of the Malams; such centers could also be found under the shade of a tree or the outer room of the compound of the Malams. Children could also be gathered in any place found suitable for their learning chosen by their teacher (Gada, 67: 2010).

Temporary structures were used for the recitation of the Qur'ān by the scholars in Nasarawa State. Such structures before were made up of corn stalks and grasses known as 'rumfa'. But nowadays, such structures were fashioned in the modern way with modern facilities. In the beginning, open places were used to teach children, but if the season is hot, shades were needed to shelter them. So in the absence of a tree or any structure nearby which can provide shade, rumfa was erected to teach students (Malam Salihu) ${ }^{5}$.

The permanent structure of the earlier Makarankun Allo in Nasarawa State was known as 'Zaure' which before, refers to the local structure of a hut built of mud roofed by corn stalks, woods and grasses. It is usually erected in front of a house and use as entrance hall to the inner side of a house (Malam Abubakar) . $^{6}$ However, nowadays Zaure were constructed in a modern way with modern facilities and other gadgets for conveniences attached to it.

\footnotetext{
5 . Malam Salihu Ibrahim Abubakar is a teacher of Makarantar allo in Nasarawa Local Government, Nasarawa State, Nigeria, in an interview on the13th October, 2012 at Abaji Road, Nasarawa, Nigeria

${ }^{6}$ Malam Abubakar is teacher of Makarantar allo at Keffi, Nasarawa State, Nigeria, in an interview on the $21^{\text {st }}$ October, 2012 at Anguwan Tudun Wada, Keffi, Nasarawa State, Nigeria
} 


\subsection{Teachers of Makarantun Allo in Nasarawa State}

Teachers of Makarantun allo in Nasarawa State were those who possessed certain qualification of religious education after studying from their own teachers who awarded them the license or certificates Ijazat to teach. However, the minimum qualification for those teachers could be the completion of recitation of the Qur'ān (Malam Muhammad Adamu) ${ }^{7}$. Teachers at this level are considered to be religiously trained who uphold the ethics of teaching. They taught it not because they wanted to earn a living but because they wanted to be among the best as described by the Prophet (S.A.W) where he said: "the best of you is one who learn the Qur'ān and teaches it" (Al-Bukhari vol. 6, no. 5027: 1984). Teachers of Makarantun allo in Nasarawa State are categorized into two- the mobile and the resident teachers. The mobile teachers are those who move from one place to another with the sole aim of teaching the Qur'ān. The mobile teachers in Nasarawa State are in two categories. The first category were those who moved together with children entrusted to them by their parents while the second category were those who moved individually visiting different places where they settled for a period of time and imparted Islamic knowledge to the people they met (Alaramma Umaru) ${ }^{8}$. On the other hand, resident teacher is the one who lives in one place and established a school where he teaches students. Such a teacher could be an indigene of the State or a stranger.

\subsection{The Ethics of Teachers of Makarantun Allo}

The ethics of teachers in Makarantun allo had for centuries been maintained as it had been taught by Prophet Muhammad (S.A.W). Later Muslim scholars also tried to preserve such ethics so that it could reach future generation of Muslims. Abdullahi Ibn Fodiyo enumerated the ethics of an Islamic teacher in his edited work Lubab al-Madkhal thus:

It is necessary that a teacher protects his noble profession by not desecrating it through contradicting or ignoring the Sunnah, or through leaving an innovation unchanged despite being aware of it and being in a position to do so (Abdullahi Ibn Fodiyo (50: 1990).

In addition, Abdullahi Ibn Fodiyo added that a teacher should first start by changing himself before making effort to change others. He does not have to change what he orders to be changed by force rather, he is only expected to speak about it verbally in more captivating manner. The scholar should be the first to obey religious commands and first to shun forbidden or reprehensible acts so that the followers would benefit from him by emulating him in doing the right thing and shunning the prohibited one (Abdullahi Ibn Fodiyo 55: 1990).

In fact, the ideal Muslim teacher should have an upright moral training that would make him a model to not only his students but the entire members of the society to which he belongs. Muslim scholars are unanimous that the character of a good teacher has more impact on the personality molding of a child than the teacher's subject matter (Al-Ghazzali, 32: 1992). The Islamic teacher is therefore, considered to be an invaluable actor in the realization of the objectives of Islamic education. Numerous verses of the Qur'ān and Hadith of the Prophet (S.A.W) revered the position of an Islamic teacher. In one of such verses Allah (SWT) says: "Allah would rise up, to (suitable) ranks (and degrees), those of you who believe and have been granted knowledge..." (Q 58:11). Although the Qur'ann is not explicit in explaining position to which the scholars could attain, but the Prophet (S.A.W) provides explanation in one of his Hadith about the excellent position of a good teacher. Abi al-Darda reported that he heard the Prophet (S.A.W) saying "Scholars are the heirs of the Prophets" (Abu Daud, vol.3, 354, no. 3643: nd).

This important position makes teaching profession to be prestigious and greatest of all other professions. Indeed, teaching as a noble profession, demand one's immense sacrifice for the salvation of mankind. Many Muslim scholars chose teaching as their profession, not for any worldly or material gain, but simply because they consider it as an obligatory duty upon themselves. (Mahdi, 239: 1985).

\subsection{Time of Study and Holidays in Makarantun Allo in Nasarawa State}

The study days of Makarantun allo in Nasarawa State starts on Saturday and ends on Wednesday. Thursday and Friday are off days for the pupils during which time they are expected to wash their clothes, shave their hair, cut their finger nails, bath themselves and help their parents or teacher by attending to some domestic tasks. This is because the school days seemed to be very busy ones as learning is done in three consecutive sessions, i.e., Morning, Afternoon and evening or night sessions. statement:

In Lubab al-Madkhal of Abdullahi Ibn Fodiyo, this timing has been made clear in the following

There is no harm in sending the children away and giving them rest for ' $i d$ (Islamic festivals). If they rest for two days in a week, they will be fresh for the rest of the week (Abdullahi Ibn Fodiyo 102-103 : 1990).

\footnotetext{
${ }^{7}$.Malam Muhammadu Adamu. Opcit

8. Alaramma Umaru is a Scholar of Makarantar allo and Tsangaya in Keffi Nasarawa State, Nigeria, in an interview on the $21^{\text {st }}$ October, 2012 at Anguwan Tudun Wada, Keffi, Nasarawa State, Nigeria. 
The two days weekly holidays (Thursday and Friday) originated from the time of the second caliph Umar Ibn Al-Khattab as reported by Az-Zarnuji in his book Ta'lim al-Muta'allim-Tariq at-Ta'-allum thus:

It was reported that Umar Ibn Al-Khattab traveled to al-Sham (Syria) at the time it was conquered. He stayed there for sometime before he came back to Madina and people were eager to see his arrival upon which they came out to welcome him. The first group in this outing were the children for their activeness and enthusiasm. They met him after a day's journey and that day was Thursday. So he was with them on that day until the next morning before they entered Madina on Friday before the prayer. Upon this he (Umar) said to the children "You are really tired. A day for your outing and a day for your coming back; as such I have declared for you Thursday and Friday to be time for holidays both for you and those to come after you until the Day of resurrection (AzZarnuji 141:2009).

From the statement of Umar Ibn al-Khattab (R.A), it become clear that the tradition regarding the time of learning and resting in the Qur'anic school had for centuries been maintained as it used to be in the early period of Islam.

\subsection{Curriculum of Makarantun Allo in Nasarawa State}

Qur'anic studies form the major part of learning in all the Muslim states including Nasarawa State. However, reading and writing were considered as advantages towards the achievement of Qur'anic studies. According to Hitti- "The curriculum of elementary school, centered upon Qur'ān as a reading text book. With reading, went writing" (Hitti, 408: 1982). Stressing the importance of the Qur'ān and the reason why it should form the basis of curriculum of Islamic education, Al-Beely (22:1980) commented thus:

Everybody concerned with Islamic education agreed that the Qur'ān is the cornerstone which links the Arabic and Islamic education. Memorization of the Qur'ān helps jurists in producing evidence, help linguists in finding examples and helps others interested in Islamic and Arabic studies whenever they need an authoritative reference. It also improves the style of public speakers and writers whenever they borrow from its elegant, inimitable words and verses.

Although, what was expressed by Al-Beely applied in the case of advance studies, but the foundation of the recitation of Qur'ān is acquired at the grassroots. Memorization of the Qur'ān starts in the Makarantun allo through rote learning. What has been studied in this stage sticks to child's memory more than what he will learn in the later age in life. The element, common to all the curricula set by different scholars is the indispensability of the studies of the Qur'ān, Hadith and Arabic Language.

Precisely, Qur'ān is considered as the source and stock of knowledge or curriculum throughout the Muslim world. This was affirmed by the comments of Ibn Khaldun who said:-

It should be known that instructing children in the Qur'ān is a symbol of Islam. Muslims have practice this instruction in all their cities because it imbues the hearts with firm belief (in Islam) and its articles of faith (301:1967).

The first thing a child is introduced to on reaching Makarantun allo in Nasarawa State was memorization of the shorter chapters particularly, from the opening chapter (Q:1) i.e. (Surah al-fatiha) to the Chapter of elephant or the chapter of the High (Q:105 or Q:87) i.e. (Surah al-fil or Surah al-'ala). He would then be introduced to the learning of alphabets without diacritical marks and then with diacritical marks so as to acquire the knowledge of reading and writing in other to enhance his ability to read by himself. Having mastered the alphabets, a child will go back to start learning the proper recitation of Qur'ān in portions from Q:114 to Q:2 (Surah al-Nas to Surah al-Baqarah) in the ascending order. At the beginning, the teacher will copy for the child, and as he progresses, the child will be given the chance to start copying for himself. After every transcription either by the teacher or by the child, a ritual of rehearsal is observed where the teacher read out the transcribed portion to the child once, twice or thrice. The materials involve in this study are the Qur'ān, a slate (allo), ink (Tawwada) and pen (alkalami) made of corn stalk (Malam Muhammad Awwal) ${ }^{9}$.

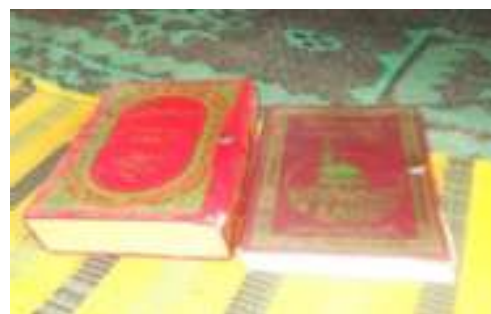

Fig 1- the Qur'ān

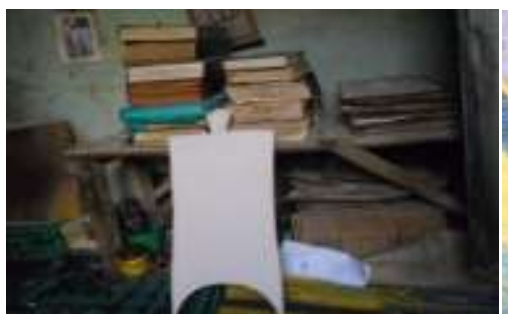

Fig 2- a wooden slate (Allo)

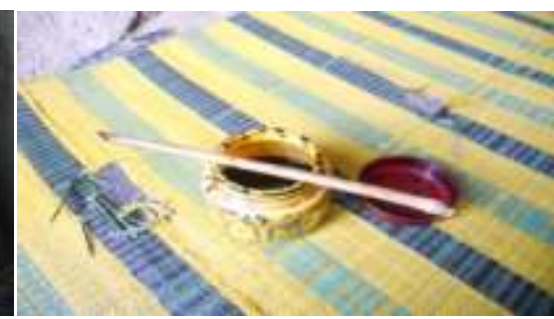

Fig 3-writing ink (Tawwada) with a pen (alkalami)

9. Malam Muhammadu Awwal. Opcit 
Besides the Qur'ān, rudiments of jurisprudence (fiqh) are taught in order to enable the child know how to pray (Hunwick 54: 1970). This is because a Muslim child is expected to commence praying at the age of seven and be flogged for his refusal to pray at the age of ten (Abu Daud, vol. 1, no. 495:nd). For this reason, in some Makarantun allo, rudimentary aspects of rituals are taught alongside the recitation of the Qur'ān. These includes purification, performance of ablution and prayers.

\subsection{Methodology of Teaching in Makarantun Allo in Nasarawa State}

Since the curriculum of this stage prescribed Qur'ān to form the basis of learning for the children, the methodology adopted by Muslim scholars in Nasarawa State right from the early days, is to introduce the easiest way to acquaint pupils with the simple way to recite the Qur'ān. The methodology of teaching in Northern Nigeria was brought by the visiting scholars. This has been confirmed by Zahraddin when he commented thus: "the educational system operational in these centers was said to be framed along the Timbuktu pattern of learning which was introduced before the $15^{\text {th }}$ Century" $(160: 1976)$.

It is important to note that the influx of Fulani, Kanuri and Nupe scholars paved way for the development of Islamic education in Nasarawa State by adopting simple methods of alphabetical identification leading towards proper understanding and mastery of reading and writing the Qur'ān. At the rudimentary stage, the teacher begins by reciting the chapter or some verses and then asks pupils to recite after him in group. Later he checks the individual mastery of what was taught to the group (Malam Dalhatu Dahiru) ${ }^{10}$.

After the oral recitation was mastered, the child would be introduced to the alphabetical studies with a view to making him identify Arabic letters while reading or writing. The Arabic alphabets and their consonant had to be written in their original Arabic forms since the Qur'ān is written and recited in Arabic. However, since the Islamic scholars in Nasarawa State comprises predominantly Hausawa, Fulani and Beri-beri people, two methods were adopted for the alphabetical studies. They include the Hausanci and Fullanci methods. The Hausanci method was the one introduced by Hausa Malams who taught the alphabets in Hausanci, while the Fullanci method was the one introduced by Fulani Malams who taught the alphabets in Fullanci. For example, the letter ( I ) is taught as "Alif" by a Hausa Malam and "Alifi" by a Fulani Malam. The letter ( $)$ ) is known as Baguje in Hausa and simply called Ba in Fullanci (Malam Awa and Alaramma Musa Bazamfare) ${ }^{11}$.

Learning of these alphabets is done in stages so that the child can identify each of the alphabets when it is used at the beginning, in the middle or at the end of a word. For example alphabet ( $\bullet$ ) comes at the

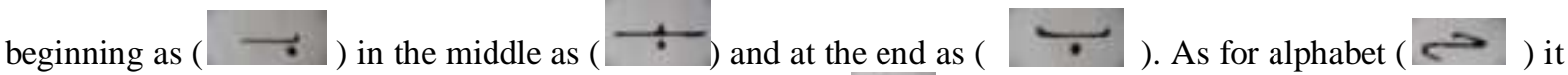
appears at the beginning as $(\vec{b})$ in the middle as $(\stackrel{-}{)}$ ) at the end as $(\vec{c})$. After identifying the alphabets, the child then move to the next stage where he will learn how to join alphabets with diacritical marks to compose a word in the following way:

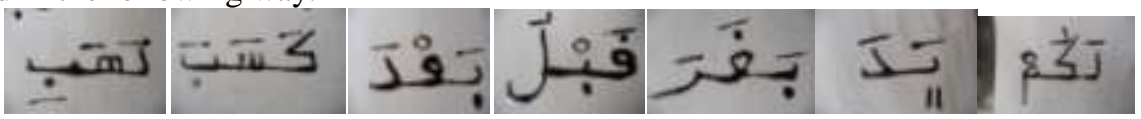

With the mastery of alphabets through stages discussed above, a child would advance further to learn the alphabets from the chapters of the Qur'ān. In this stage, the opening chapter (Q:1) (Surah al-fatiha) would be written on his slate without diacritical marks in the following way:-

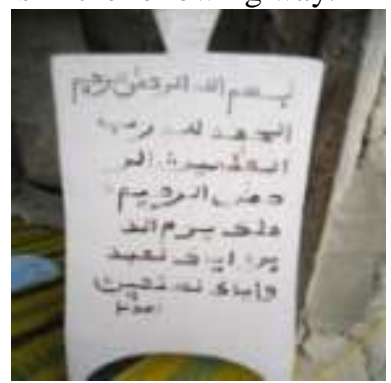

Fig.4- a slate with some parts of Suratul Fatiha without diacritical marks

In this way, a child would learn to identify these alphabets in the shorter chapters from Q:1 to Q:105 (Surah alfatihah to Surah al fil) in the same way, he memorize them through rote learning. After reaching Q: 105 (Surah

\footnotetext{
${ }^{10}$.Malam Dahiru Dalhatu is the Chief of Lafia Central Mosque in Nasarawa State, Nigeria and a teacher of Makarantar allo, in an interview on the $2^{\text {nd }}$ Nov. at Anguwan Toni Lafia, Nasarawa State, Nigeria.

11. Malam Musa is a teacher of Makarantar allo in Lafia, Nasarawa State, Nigeria, in an interview on the $2^{\text {nd }}$ November, 2012, at Lafia, Nasarawa State, Nigeria.
} 
al-fil), a child would then go to the next stage of studying the shorter chapters with diacritical marks starting from Q:1 (Surat-al-Fatihah) in the following way:

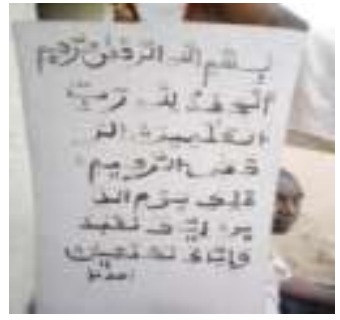

Fig 5- a slate with some part of opening chapter (Suratul Fatiha) with diacritical marks

In this way, a child would continue his studies which will lead to the mastery and perfection on his recitation of the Qur'ān. Gradually, he would learn how to write by himself on his slate by the use of ink known as tawwada and subsequently, he would reach a stage when he would cease to use slate (allo) but rather a copy of the Qur'ān for his studies. At this stage, the teacher only introduces the child to the chapter of his study and recites for him, afterwards he leaves him to continue recitation by himself. He would continue like this, until he completes his studies of all the chapters of the Qur'ān (Malam Muhammad Ali) ${ }^{12}$.

\subsection{Remuneration for Teachers of Makarantun Allo in Nasarawa State}

The issue of taking remuneration for teaching the Qur'ān has been discussed by the early Muslim scholars. Some of them considered it lawful while others disallowed it. Imam Malik was among those who allowed it. These views were expressed in verse by Abdullahi Ibn Fodiyo in his work Fara'id al-Jalilah he said: Teaching for remuneration wholly is allowed according to Imam Malik. It is totally disallowed by Ibn Thabit. Other recommended rewards for it. However, view of Imam Malik is the right one for there is clear consensus on it (Abdullahi Ibn Fodiyo (98:1981).

The consensus referred to here according to Imam Malik is the fact that there are evidence from the Qur'ān, Hadith and the deeds of the people of Madina. In the Qur'ān, Allah says: "but help ye one another unto righteousness and pious duty. Help not one another unto sin and transgression..." (Q 5:2). The argument brought forward by Imam Malik after quoting this verse was that there is no righteous deed which is better than paying for the teaching of the Qur'ān. He quoted a Hadith in which the prophet (SAW) Said: "Verily the most befitting of whatever you received remuneration for it, is the book of Allah" (Al-Bukhari,vol.7,no. 5737:1984).

It was because of the evidences cited above that the people of Madina endorsed and recommended giving remuneration to the teachers of Qur'ān. However, this remuneration was restricted to the teachers of the Qur'ān who are competent enough and are well versed in the knowledge of proper recitation of the Qur'ān (Tajwid). For this therefore, it is recommended that there should be an agreement regarding the duration and the amount to be paid as remuneration. For instance, remuneration for the people of Madina had been specified in stages and in accordance with the child's mastery of the portions of his recitation of the Qur'ān. If a child mastered the recitation and writing of particular verses or chapter of the Qur'ān, then his teacher is entitled to his remuneration accordingly. If he mastered up to Q:67(Surah al Mulk), the teacher will be entitled to a remuneration of 4 dinar, if he reaches Q:48 (Surah al Fath), the teacher is entitled to 8 dinar and for reaching Q:19 (Surah Maryam) the teacher is entitled to 12 dinar while the completion of the whole Qur'ân will attract a remuneration of 16 dinar (Abdullahi bn Fodiyo 105-106: 1990).

Accordingly, remuneration for teachers in Makarantun Allo in Nasarawa State are in a form occasional presents by the parents of the children given to the teacher so as to boost his morale in taking proper care of the learning process and morality of their pupils. This is probably why in Nasarawa State, periodic presents were made to teachers. They include the entry fees known as Kudin Bulala or Dorina. This is the token amount given to the teacher as soon as the child is first admitted into the Makarantun allo. It means money for buying cane so as to take proper care of the child. He can be flogged for any misbehaviour and lack of concentration to his studies (Gada 90: 2010).

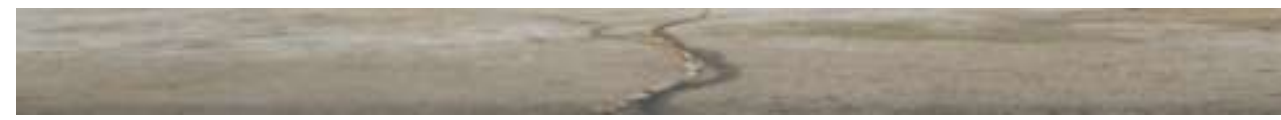

Fig 6. The cane (Dorina or Bulala)

\footnotetext{
12. Malam Muhammad Ali is a teacher of Makarantar allo in Lafia, Nasarawa State, Nigeria, in an interview on the $2^{\text {nd }}$ November, 2012 in Lafia, Nasarawa State, Nigeria
} 
The weekly fees known as Kudin sati is another occasional remuneration given to the teachers of Makarantun allo in Nasarawa State. This is a weekly fees given to the teacher to take care of his household as he does not engage in any business other than teaching the children; and the money given to the teacher on the occasion of child's passage from one chapter to another known as Kudin Rubutu or Kudin Kafin Alkalami, when the child was given the permission to wash his slate (allo) and a new chapter be written on it (Malam Dalhatu Dahiru) ${ }^{13}$.

In addition, other fees includes Kudin Mai, which is paid weekly for buying kerosene for the lantern or materials to be used in the school during night sessions, Kudin hutu or Kudin fitan makaranta which is paid when the school is going for long vacation specifically during the month of Ramadan, as well as other seasonal present known as "Sadaka" also served as part of remuneration to the teachers of Makarantun allo in Nasarawa State. These could be in form of cash or kind. Part of these were Zakah by rich parents of children attending a particular school, bundles of the harvested grains at the end of rainy season, grains meant for Zakat al-fitri, money or animals were occasionally sent to teachers of Makarantun allo (Malam Muhammadu Adamu) ${ }^{14}$. Therefore, it should be made clear that there was no fixed remuneration paid by parents resulting from agreement with teachers of their children.

\subsection{Graduation ceremony and occasion feasts in Makarantun Allo in Nasarawa State}

Teachers of Makarantun Allo in Nasarawa State adopted several traditional methods of encouraging their pupils to learn the Qur'ān. These methods often made pupils to be very much zealous in their studies so that they can graduate. The method were in form of occasional feasts and celebration marking the attainment of certain levels in learning the Qur'ān i.e. (Abdullahi Ibn Fodiyo 147-148: 1981). The feast celebrations have been introduced to cover even the earliest stage in the learning of Qur'ān. For example if a child mastered recitation up to (Q:105) i.e. Surah al-fil, his parents cooked food and sent to the teacher for distribution to the entire pupils in the school. Special share was normally taken to the house of the teacher for his own family.

When a child, through his mastery in both reading and writing reached Q:87 (Surah al-'Ala), his parents cook food and send to the school. The child's ability to learn the recitation of the Qur'ān up to Q:78 (Surah al-Naba) would earn him more encouragement from his parents who will be over joy to cook more abundant and delicious food to send to the school for another feast celebration (Malam Muhammadu Adamu) ${ }^{15}$.

The graduation ceremony is the most attractive of all the occasional ceremonies witnessed in the Makarantun allo. This is the occasion marking the ability of the child to complete the recitation of the Qur'ān. The occasion is accompanied by a decoration of a child's slate with various forms of calligraphy (zayyana).

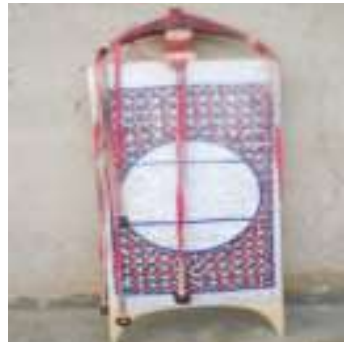

Fig.7- Decorated slate of a child who completed the recitation of the Qur'ān

At this point, the parents of the child will be informed of his ability to complete the recitation of the Qur'ān. Enthusiastically, a bigger feast would be organized known as Addu'ar Sauka (Malam Muhammadu Adamu $)^{16}$. These kinds of celebrations were considered by early Muslim scholars as permissible simply because they make the child happy and encouraged him to concentrate more on his studies, it also encourage other pupils to put more effort; and make his parents and teachers happy for the achievement of their desired objectives of successfully providing moral training and religious education to their child.

In summary, Makaratun allo has left tremendous impact on the life of the people of Nasarawa State in the following areas:

-unity and solidarity among the Muslims, hence there is a very strong sense of brotherhood among the people of Nasarawa State.

-mode of dressing of the Muslim children and adults in the State.

-encourage literacy, sustenance of religious morals and social cohesion

\footnotetext{
${ }^{13}$ Malam Dahiru Dalhatu. Opcit.

${ }^{14}$ Malam Muhammadu Adamu. Opcit.

${ }^{15}$ Malam Muhammadu Adamu, Ibid.

${ }^{16}$ Malam Muhammadu Adamu. Ibid
} 
-helped to spread civilization, as Muslim children and adults travelled to other places, to learn from those places and brought back this knowledge to their various communities.

-sense of unity of belief, because prior to its advent there were many gods and goddesses who had many confusing function.

\section{Conclusion}

In conclusion, Makarantun allo even though is currently losing its relevance in Nasarawa State due to the priority given to western secular education; it has at the same time succeeded where formal education fails because it had perfectly adjusted itself to the economic life of the people. The academic time-table and school calendar unlike the formal schools was designed in such a way that it will not take away the benefits of full-time apprenticeship and assistance of young children in farm-work. The Makarantun allo system has many more features which makes it more appropriate for a society like Nasarawa State. For example, flexibility of attendance is a feature of Makarantun allo. Regular attendance, though required, is not rigidly enforced. This enables those whose economic and social commitments prevent them from maintaining regular attendance to attend school at their own time and convenience. Commenting on this flexibility, Bray et al (80:1986) stated that:

The Islamic system is in many respects far less dependent for its operation on specific administrative, institutional and organizational patterns. It also tends to be much more flexible and has 'an admirable leisureliness'.

Moreover, the Qur'anic schools have multiple entry points which also are not fixed. Students can enroll into the schools at any time of the year, provided it is a session. Another important feature which makes Makarantun allo more readily acceptable to the ordinary people in Nasarawa State is its egalitarian outlook as observed Malam Badamasi ${ }^{17}$ that:

Formal education is expensive so much that the parents can neither afford its direct cost nor the routine expenditure for the children. The absence of these economic problems in Makarantun allo often makes the parents to prefer the system.

In addition, considering the perennial nature of poverty in Nasarawa State, not many parents could afford the cost of formal education like school fees, uniform, text and note-books, feeding and transportation. Therefore, even though the values of Western education are recognized in Nasarawa State, the need to escape the problems of its financial expenditure, seems to have out-weighs the desire to acquire it; thus in sharp contrast with the Makarantun allo which seems to be egalitarian in outlook and in perfect rhythm with the dominant economic activity of the people of Nasarawa State which is agricultural production.

By way of recommendation, this paper recommends that there should be political will on the part of the governments at all levels of administration to seriously support and strengthen slate schools (Makarantun allo) within the mainstream of the Nigeria educational policies; in addition to developing an acceptable framework in which all stakeholders will participate fully in providing the necessary input to the success of Makarantun allo in Nasarawa State in particular and Nigeria in general.

\section{Works Cited}

[1] Abdullahi bn Fodiyo, Fara'id al-Jalilah, (ed) Abdul Ali Abdul-Hamid, Beirut: Dar al Fikr, 1981

[3] Abu Dawud, Ibn al-Ash'ath, Sunan Abi Dawud, Beirut: Darul Fikr, n.d.

[4] Al-Beely, U.A, Islamic Concept of Educational Curricular, in the Curriculum and Teacher Education, Islamic Education Series, Jeddah: Hodder and Staughton, King Abdul Aziz University, 1980.

[5] Al-Bukhari, Muhammad Ibn Ismai'1. The Translation of the Meaning of Sahih al-Bukhari.(Trans), Muhammad Muhsin Khan, New Delhi: Kitab Bhavan, 1984.

[6] Al-Ghazzali, M, Muslim Character, Kuwait: Al-Faisha Press, 1992.

[7] Az-Zarnuji, B. I, Ta'lim al-Muta'allim-Tariq at-Ta'-allum Karachi: Qadimi Kutub Khanna, Arambagh, 2009.

[8] Bray, M, P.B. et al, Education and Society in Africa, London: Edward Arnold Ltd, 1986.

[9] Fafunwa, A. B., History of Education in Nigeria, London: George Alien and Unwin LTD, 1976.

[10] Gada, A.M, A Short History of Early Islamic Scholarship in Hausaland, Kaduna: Department of Islamic Studies, UDUS,2010.

[11] Hiskett, M. The Development of Islam in West Africa, London: Cambridge University Press, 1984.

[12] Hitti, P. K, History of the Arabs, $10^{\text {th }}$ edition, London: Macmillan Press, 1982.

[13] Hunwick, J.O. A Sixteen Century African Scholar: Muhammadu Baghaygho, in Studies in Memory of Kwame Yebah Da Aku, London: Cambridge University Press, 1970.

[14] Ibn Alhaj, Abdari, Al-Madkhal, California: Mazda Publishers, 1995.

[15] Ibn Khaldun, Al-Muqaddimah,, Franz Resential (trans), vol 3, London: Routledge and Keagan, 1967.

[16] Ibn Majah, Sunanu Ibn Majah, (eds) Yasir Ramadan and Muhammad Abdallah, vol.1, Cairo: Dar bn Haitham, 2005.

[17] Mahdi, M. Lesson from Islam, Karachi: Islamic Seminary Publication, 1985

[18] Muslim bn Hajjaj, Sahih Muslim, (Trans) Muhammad Ashraf, Beirut: Dar al-Fikr, 1978.

[19] Zahraddin, M.S. "Abdullahi bn Fodiyo's Contribution to the Fulani Jihad in the $19^{\text {th }}$ Century Hausaland", Unpublished Ph.D. Thesis, Mc-Gill University, 1976. 